Saudi Journal of Business and Management Studies Abbreviated Key Title: Saudi J Bus Manag Stud ISSN 2415-6663 (Print) |ISSN 2415-6671 (Online) Scholars Middle East Publishers, Dubai, United Arab Emirates Journal homepage: https://saudijournals.com/sibms

Original Research Article

\title{
"A Study on Impact of Cross-Market Spill-Over on Indian Stock Market" (With Special Reference to USA, CHINA, and JAPAN)
}

Kishore Meghani"

Research Scholar M.B.A. Finance, M.A. Economics., M.Com. Accounts \&Law, CBSE-UGC-NET (Commerce) NSE Academy Certified Market Professional (NCMP)- Level 1 Ex-Branch Head, The Nainital Bank Ltd.

DOI: $10.36348 /$ sjbms.2020.v05i07.003

| Received: 18.06.2020 | Accepted: 25.06.2020 | Published: 08.07.2020

*Corresponding author: Kishore Meghani

\section{Abstract}

The term volatility is simply synonymous with risk: in their view high volatility is to be deplored, because it means that security values are not dependable and the capital markets are not functioning as well as they should [22]. It measures how for the current price of an asset deviates from its average past values. The coefficients also suggest spillovers from the returns to the sentiments across markets. The coefficients indicate that high absolute sentiment scores in the stock market are expected to have an increasing influence on the commodity returns and a decreasing influence on the stock returns of the following day.

Keywords: Volatility, Spillovers, Stock Market, Bombay Stock Exchange (BSE).

Copyright @ 2020: This is an open-access article distributed under the terms of the Creative Commons Attribution license which permits unrestricted use, distribution, and reproduction in any medium for non-commercial use (NonCommercial, or CC-BY-NC) provided the original author and source are credited.

\section{INTRODUCTION}

Merton Miller [1], the winner of the 1990 Nobel Prize in Economics wrote in his book Financial Innovation and Stock Market Volatility - "By volatility public seems to mean days when large market movements, particularly down moves, occur. These precipitous market wide price drops cannot always traced to a specific news event. Nor should this lack of smoking gun be seen as in any way anomalous in market for assets like common stock whose value depends on subjective judgment about cash flow and resale prices in highly uncertain future. The public takes a more deterministic view of stock prices; if the market crashes, there must be a specific reason".

\section{LITERATURE REVIEW}

Chatrath, Ramchander and Song [2], examined the relationship between the Indian stock market and the stock markets of the U.S. and other developed countries using daily data for the period 1984 to 1992. They used the Bombay Stock Exchange National Index (BSENI) and the Dow Jones Industrial Average (DJIA) as representative indexes for the Indian and U.S. markets, respectively. The authors identify two major concerns in portfolio diversification studies. First, return comparisons between countries are exposed to currency risk. Second, correlations between stock returns for various countries must be stable over time in order to be able to employ past correlations as a proxy in creating optimal portfolios. They find that the Indian stock market had low correlations with the markets of the developed countries. Therefore, the Indian market offered diversification benefits for investors in the developed countries for the period 1984 to 1992.

Barry, Peavy III and Rodriguezz [3], examined the return characteristics of emerging stock markets along with returns to several U.S. market indexes. They conclude that investments in emerging markets increased in importance because many investors from developed nations believe that markets in the developing countries have the potential for high returns along with increased diversification benefits. The authors find that the emerging markets do not consistently generate high returns. However, these markets continue to provide diversification benefits for investors from the developed countries. The authors 
find that the relative ranking of returns between developed and emerging stock markets largely depends on the time period. Therefore, optimal asset allocation between developed and emerging markets changes over time.

Arshanapalli and Kulkarni [4], examined the relationship between the U.S. and the Indian stock markets. They explain that this relationship is important because of the transformation of the Indian economy to a more open economy over the decade of the nineties. The authors state that increased integration with developed nations is beneficial to India's economic prosperity, but greater integration with the world economy also makes the Indian economy more vulnerable to outside risk. The authors collected daily data for one Indian index (the BSE 30 Index) and two U.S. indexes (the NASDAQ composite and the NYSE composite) for the period January 1991 to December 1999. They expected the Indian stock index to be more integrated with NASDAQ than with the NYSE composite because the majority of the Indian companies listed in the U.S. over that time period were in the NASDAQ index. Most of these companies became listed by NASDAQ during 1998 and 1999. In order to test the hypothesis, the authors divided their data into two sub-periods, pre-1998 and 1998-99. They found that the NASDAQ index was more highly correlated with the Indian stock market than was the NYSE index. Furthermore, the correlation increased from the first sub-period (pre-1998) of their study to the second subperiod (1998-99).

Patel [5], examined the relationship between the U.S. stock market and ten emerging markets of Asia. He utilized Morgan Stanley Country Indexes as representative stock market indexes during the period January 1993 to December 2001. Patel analyzed two sub-periods defined by the 1997 Asian financial crisis: January 1991 to June 1997, and July 1997 to December 2001. The second sub-period generated generally lower returns in comparison to the first for stock markets of almost all countries, including the U.S. The correlation coefficients of stock market returns for the ten Asian emerging markets increased with those of the U.S. market during the second sub-period. Patel concluded that, in recent years, the emerging markets have become more integrated with the U.S. stock market. He also found that the correlations of returns between the U.S. market and the South Asian stock markets of India, Pakistan and Sri Lanka continued to remain low during the second sub-period in comparison with the correlations for the other emerging markets of Asia. The Indian stock market is considerably larger than the other two South Asian markets. Patel suggests the need for researchers to further examine the Indian stock market to determine whether it continues to provide investment opportunities and diversification benefits to U.S. investors.
Rahman [6], examined the impact of index futures trading on the volatility of component stocks for the Dow Jones Industrial Average (DJIA). The study used a simple GARCH $(1,1)$ model to estimate the conditional volatility of intra-day returns. The empirical results confirm that there is no change in conditional volatility from pre- to post-futures periods.

Figuerola-Ferretti and Gilbert [7], used errorcorrection models and the $\mathrm{GARCH}(1,1)$ regression model to study the effect of futures trading on volatility. In addition, they reported the results of a VAR model and presented an impulse response analysis to track the effects of a shock to each of the volatilities. The results show that volatility decreases in the post-futures period.

Bologna and Cavallo [8], examined the effect of the introduction of stock index futures for the Italian market. Their empirical results show that the introduction of stock index futures affects the volatility of the spot market. In addition, the results from various GARCH $(1,1)$ models for pre-futures and post-futures sub-periods suggest that the index futures market reduces volatility.

Chiang and Wang [9], examined the impact of futures trading on Taiwan spot index volatility. Their study also discussed the macroeconomic and asymmetric effects of futures trading on spot price volatility behaviour. They used an asymmetric timevarying GJR volatility model. Their empirical results showed that the trading of futures on the Taiwan Index has stabilising impacts on spot price volatility, while the trading of MSCI Taiwan futures has no effects, except asymmetric response behaviour.

Patel [5], examined the relationship between ten emerging stock markets of Asia (including India) and the U.S. stock market. He reports that the correlation between returns in the emerging markets of Asia and U.S. stock a well-known stylized fact in stock markets is that volatility tends to vary over time [1012].

Thenmozhi [13], examined whether there was any change in the volatility of the S\&P CNX Nifty Index in India due to the introduction of Nifty futures and whether movements in futures prices provided predictive information regarding subsequent movements in index prices. The study shows that the inception of futures trading has reduced the volatility of spot index returns.

Pilar and Rafael [14], analysed the effect of the introduction of derivatives on the Ibex-35 Index using a dummy variable and a GJR model to test the impact of the introduction of derivative markets on the conditional volatility of the underlying asset. They found that although the asymmetry coefficient increased, the 
conditional volatility of the underlying index declined after derivatives were introduced.

Robert and Michael [15], investigated the impact of the introduction of stock index futures trading on the seasonality of daily returns of the underlying index for seven national markets. The results indicate reduced seasonality with respect to mean returns, thus leading to more efficiency in these markets.

Shembagaraman [16], explored the impact of the introduction of derivative trading on cash market volatility using data on stock index futures and options contracts traded on the Nifty Index. The results suggest that futures and options trading has not led to a change in the volatility of the underlying stock index, but the nature of volatility seems to have changed in the postfutures market. The study also examined whether greater futures trading activity in terms of volume and open interest was associated with greater spot market volatility. It found no evidence of any link between trading activity variables in the futures market and spot market volatility.

Sung, Taek and Park [17], studied the effect of the introduction of index futures trading in the Korean markets on spot price volatility and market efficiency of the underlying KOSPI 200 stocks relative to the carefully matched non-KOSPI 200 stocks; they found evidence that market volatility was not affected by futures trading, while market efficiency was improved. Taylor [18] tried to uncover the determinants of trading intensity in futures markets. In particular, the time between adjacent transactions on the FTSE 100 index futures market was modelled using various augmentations of the basic autoregressive conditional duration (ACD). As predicted by various market microstructure theories, he found that the bid-ask spread and transaction volume have a significant impact on subsequent trading intensity. However, there was evidence that a large (small) difference between the market price and the theoretical price of the futures contract, which is known as pricing error, leads to high (low) levels of trading intensity in the subsequent period.

Boyer and Popiela [19], looked into whether the introduction of futures to the S\&P500 Index altered the effect of addition to, or removal from, the S\&P500 Index. This study used the S\&P500 price effect to show that overall price volatility did not show any significant increase for added stocks after trading began on the S\&P500 Index futures.

Floros and Vougas [20], examined the effect of futures trading on the volatility of the underlying spot market taking the FTSE/ASE-20 and FTSE/ASE Mid 40 Indices in Greece. The results for the FTSE/ASE-20 Index suggest that futures trading has led to decreased stock market volatility, but the results for the
FTSE/ASE Mid 40 Index indicate that the introduction of stock index futures has led to increased volatility, while the estimations of the unconditional variances indicate a lower market volatility after the introduction of stock index futures.

Sibani and Uma [21], used OLS and GARCH techniques to capture the time-varying nature of volatility and volatility clustering phenomenon of the Nifty Index due to the introduction of futures trading. The results suggest that there are no significant changes in the volatility of the spot market of the Nifty Index, but the structure of volatility changes to some extent. The study also reported that new information is assimilated into prices more rapidly than before, and there is a decline in the persistence of volatility since the introduction of futures trading.

\section{OBJECTIVE \& METHODOLOGY Objectives}

1. To study the factors associated with stock market volatility.

2. To evaluate the impact of selected global indices on Indian stock market and its risk-return propositions during 2001-2013.

3. To check interdependency of Indian and global stock indices movements.

4. To assess perception of investors as to impact of international stock market volatility on stock market of emerging economy like India.

\section{DATA AND METHODOLOGY}

Data were collected from BSE Sensex for calculating return and volatility. Sensex is a basket of 30 constituent stocks representing a sample of large, liquid and representative companies. Due to its wide acceptance amongst the Indian investors, sensex is regarded the pulse of the Indian stock market.

Data were taken from 2001 to 2013. Return, Coefficient of risk, multiple regression is calculated by using SPSS.

The study has used International Organization of Securities Commission (IOSCO) classification to categorize countries into emerging and developed markets. Exhibit 1 shows the name of the countries and respective index covered in this study.

Exhibit-1: Name of the countries and respective index

\begin{tabular}{|l|l|}
\hline Country & Index \\
\hline INDIA & BSE 30 \\
\hline USA & NASDAQ \\
\hline JAPAN & SANGHAI \\
\hline CHINA & NIKKI \\
\hline
\end{tabular}

For II and III Objectives:

- Data Source : Investors

- Data Collection : By questionair

- $\quad$ Sample Size : 58 
- Sampling Design :

- Sample Locale :

Snowball Sampling

Agra, Uttar Pradesh

\section{DATA ANALYSIS AND INTERPRTATION}

Objective 1

Study the factors associated with stock market volatility

Stock market is something where you can never foretell what is going to happen in the market. You might get huge gain or incur losses when the stock market crashes. There are many factors affecting share prices.

1- Demand and Supply

2- Market cap - market capitalization.

3- Earnings per share

4- Impact of news

5- Internal Developments

6- World Events
7- Inflation and Interest Rates

8- Exchange Rates

9- Hype

10- New trading trends on the Internet

11- Stock price effects

12- Performance of Colombo Stock Exchange and Treasury Bill Rate Investment effects

13- Bottom line

14- Investor sentiment

15- Economic factors i.e.- Interest rates, Economic outlook, Inflation, Deflation, Economic and political shocks

\section{Objective 2}

To evaluate the impact of selected global indices on Indian stock market and its risk-return propositions during 2001-2013.

BSE CLOSE compare with NASDAQ CLOSE

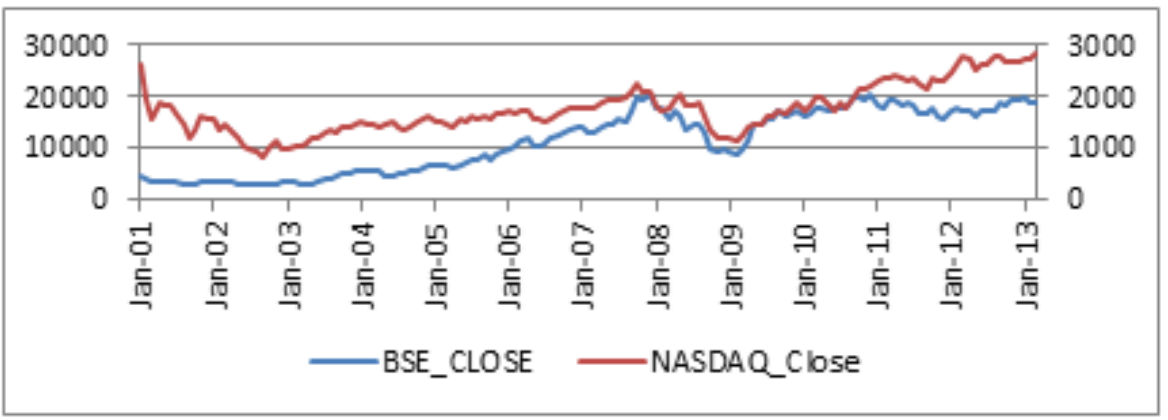

BSE CLOSE compare with NIKKIE CLOSE

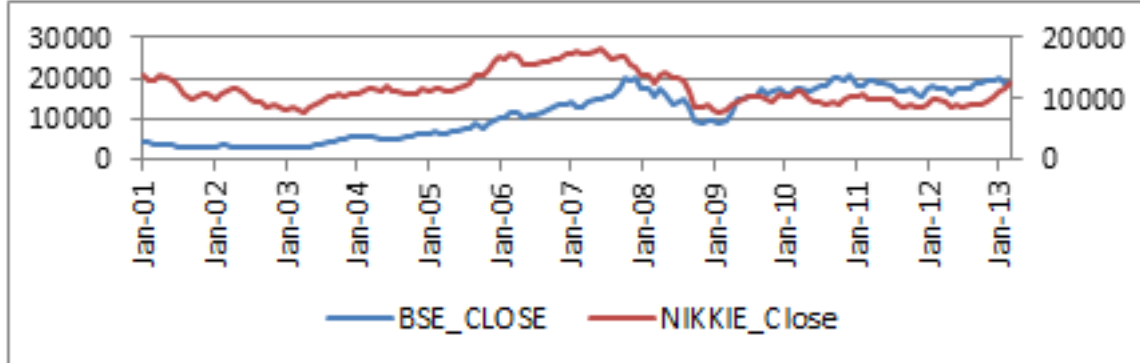

BSE CLOSE compare with SHANGHAI CLOSE

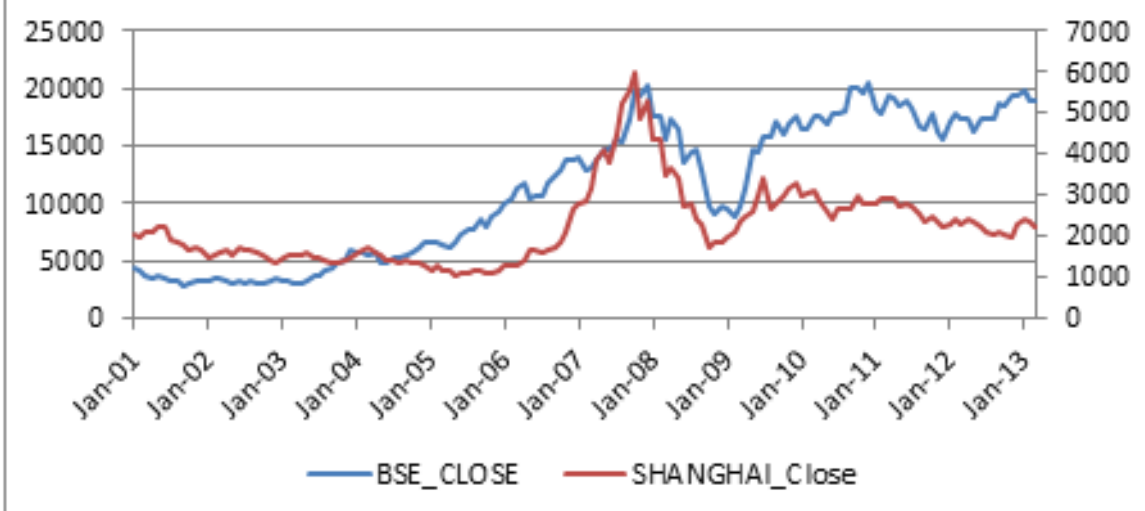


a. Determine the multiple regression equation for the data

\begin{tabular}{|c|c|c|c|c|c|c|}
\hline \multicolumn{7}{|c|}{ Coefficients $^{\mathrm{a}}$} \\
\hline \multirow{2}{*}{\multicolumn{2}{|c|}{ Model }} & \multicolumn{2}{|c|}{ Unstandardized Coefficients } & \multirow{2}{*}{$\begin{array}{c}\text { Standardized Coefficients } \\
\text { Beta }\end{array}$} & \multirow[t]{2}{*}{$\mathrm{T}$} & \multirow[t]{2}{*}{ Sig. } \\
\hline & & $\mathrm{B}$ & Std. Error & & & \\
\hline \multirow[t]{4}{*}{1} & (Constant) & -5835.817 & 1382.243 & & -4.222 & .000 \\
\hline & NIKKIE_Close & -.225 & .096 & -.103 & -2.348 & .020 \\
\hline & NASDAQ_Close & 7.549 & .589 & .588 & 12.806 & .000 \\
\hline & SHANGHAI_Close & 2.865 & .304 & .455 & 9.430 & .000 \\
\hline
\end{tabular}

From the above output, the regression equation is:

$y^{\wedge}=-5835.817+-.225 x 1+7.549 x 2+2.865 x 3$

b. Compute and interpret the coefficient of multiple determinations, $R 2$.

\begin{tabular}{|l|c|c|c|r|}
\hline \multicolumn{5}{|c|}{ Model Summary } \\
\hline Model & $\mathrm{R}$ & R Square & Adjusted R Square & Std. Error of the Estimate \\
\hline 1 & $.868^{\mathrm{a}}$ & .754 & .749 & $3.0247219 \mathrm{E} 3$ \\
\hline \multicolumn{5}{|c|}{ a. Predictors: (Constant), SHANGHAI_Close, NIKKIE_Close, NASDAQ_Close } \\
\hline
\end{tabular}

The coefficient of multiple determination is .754 .The regression equation appears to be very useful for making predictions since the value of $\mathrm{R} 2$ is close to 1 .

c. At the $5 \%$ significance level, determine if the model is useful for predicting the response.

\begin{tabular}{|l|l|r|r|r|r|c|}
\hline \multicolumn{7}{|c|}{ ANOVA $^{\mathbf{b}}$} \\
\hline Model & Sum of Squares & df & Mean Square & F & Sig. \\
\hline \multirow{2}{*}{1} & Regression & $4.014 \mathrm{E} 9$ & 3 & $1.338 \mathrm{E} 9$ & 146.236 & $.000^{\mathbf{a}}$ \\
\cline { 2 - 7 } & Residual & $1.308 \mathrm{E} 9$ & 143 & 9148942.689 & & \\
\cline { 2 - 6 } & Total & $5.322 \mathrm{E} 9$ & 146 & & & \\
\hline
\end{tabular}

At the $\langle=0.05$ level of significance, there exists enough evidence to conclude that at least one of the predictors is useful for predicting BSE close therefore the model us useful

\section{BSE COR compare with NASDAQ COR}

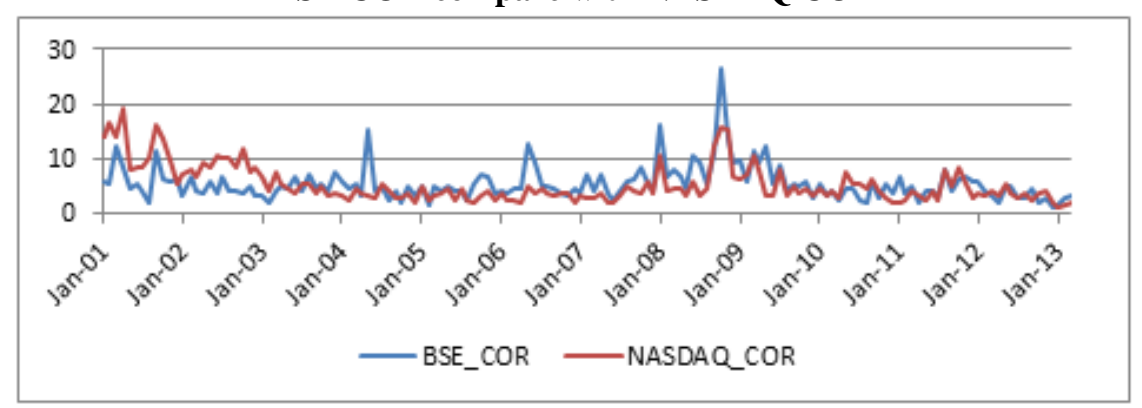

BSE COR compare with NIKKIE COR

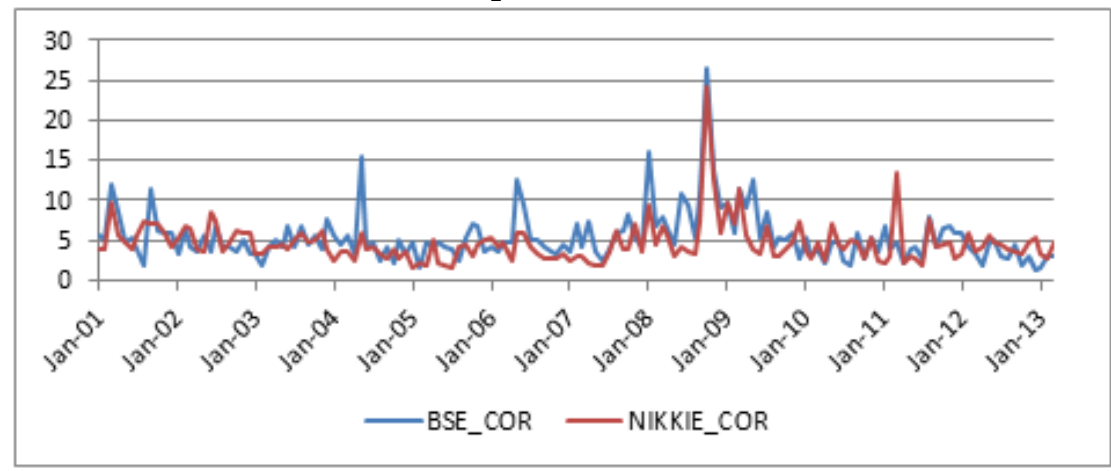




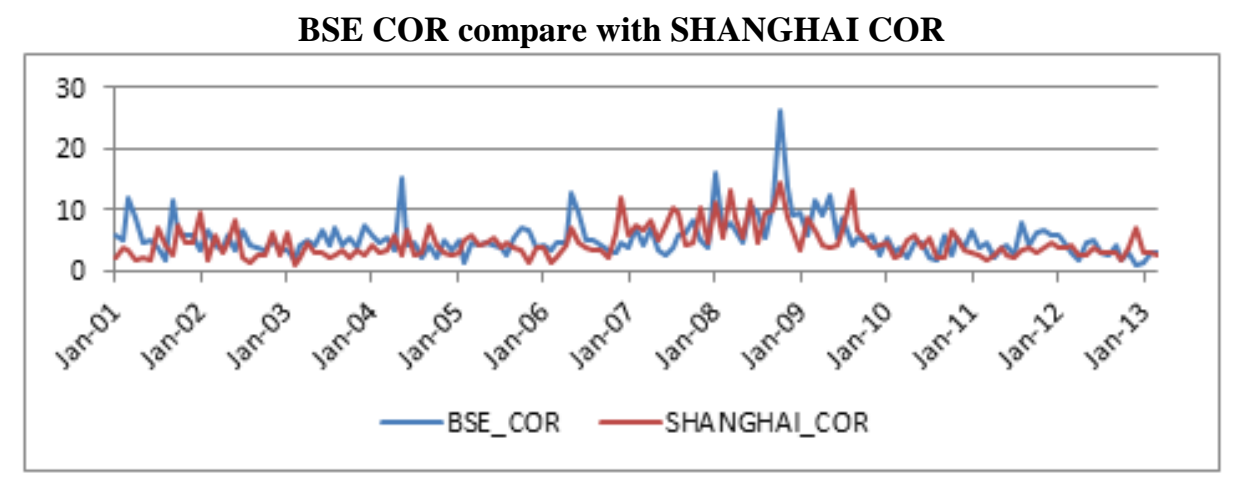

a. Determine the multiple regression equation for the data.

\begin{tabular}{|c|c|c|c|c|c|c|}
\hline \multicolumn{7}{|c|}{ Coefficients $^{\mathrm{a}}$} \\
\hline \multirow{2}{*}{\multicolumn{2}{|c|}{ Model }} & \multicolumn{2}{|c|}{ Unstandardized Coefficients } & \multirow{2}{*}{$\frac{\text { Standardized Coefficients }}{\text { Beta }}$} & \multirow[t]{2}{*}{$\mathrm{t}$} & \multirow[t]{2}{*}{ Sig. } \\
\hline & & B & Std. Error & & & \\
\hline \multirow[t]{4}{*}{1} & (Constant) & .615 & .501 & & 1.227 & .222 \\
\hline & NASDAQ_COR & .155 & .070 & .165 & 2.200 & .029 \\
\hline & NIKKIE_COR & .615 & .096 & .497 & 6.392 & .000 \\
\hline & SHANGHAI_COR & .236 & .078 & .194 & 3.035 & .003 \\
\hline
\end{tabular}

From the above output, the regression equation is:

$y^{\wedge}=-.615+.155 \times 1+.615 \times 2+.236 \times 3$

b. Compute and interpret the coefficient of multiple determinations, $R 2$.

\begin{tabular}{|c|c|c|c|c|}
\hline \multicolumn{5}{|c|}{ Model Summary } \\
\hline Model & $\mathrm{R}$ & R Square & Adjusted R Square & Std. Error of the Estimate \\
\hline 1 & $.685^{\mathrm{a}}$ & .469 & .458 & 2.3594935 \\
\hline
\end{tabular}

The coefficient of multiple determinations is .469 .The regression equation appears to be very useful for making predictions since the value of $\mathrm{R} 2$ is close to 1 .

\begin{tabular}{|c|c|c|c|c|c|c|}
\hline \multicolumn{7}{|c|}{ ANOVA $^{b}$} \\
\hline \multicolumn{2}{|c|}{ Model } & Sum of Squares & $\mathrm{df}$ & Mean Square & $\mathrm{F}$ & Sig. \\
\hline \multirow[t]{3}{*}{1} & Regression & 703.723 & 3 & 234.574 & 42.135 & $.000^{\mathrm{a}}$ \\
\hline & Residual & 796.111 & 143 & 5.567 & & \\
\hline & Total & 1499.834 & 146 & & & \\
\hline \multicolumn{7}{|c|}{ a. Predictors: (Constant), SHANGHAI_COR, NASDAQ_COR, NIKKIE_COR } \\
\hline \multicolumn{7}{|c|}{ b. Dependent Variable: BSE_COR } \\
\hline
\end{tabular}

At the $\langle=0.05$ level of significance, there exists enough evidence to conclude that at least one of the predictors is useful for predicting BSE coefficient therefore the model us useful.

\section{BSE RETURN compare with NASDAQ RETURN}

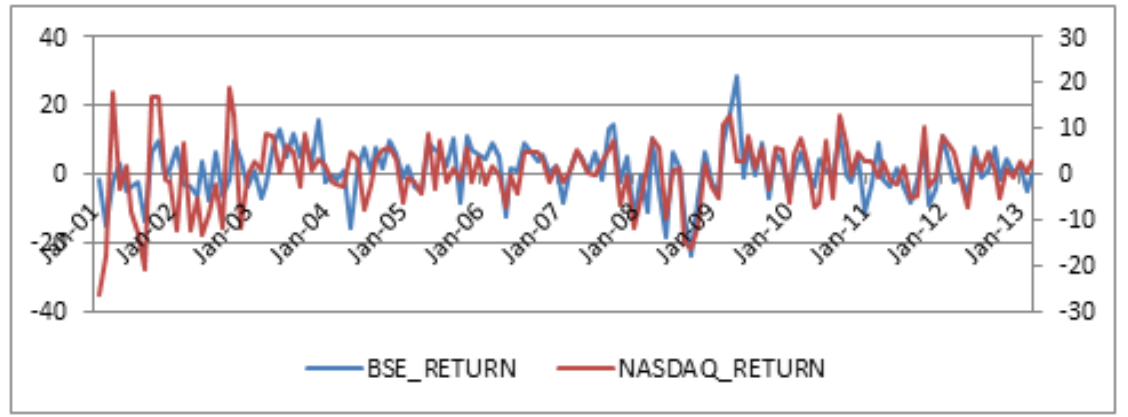


BSE RETURN compare with NIKKIE RETURN

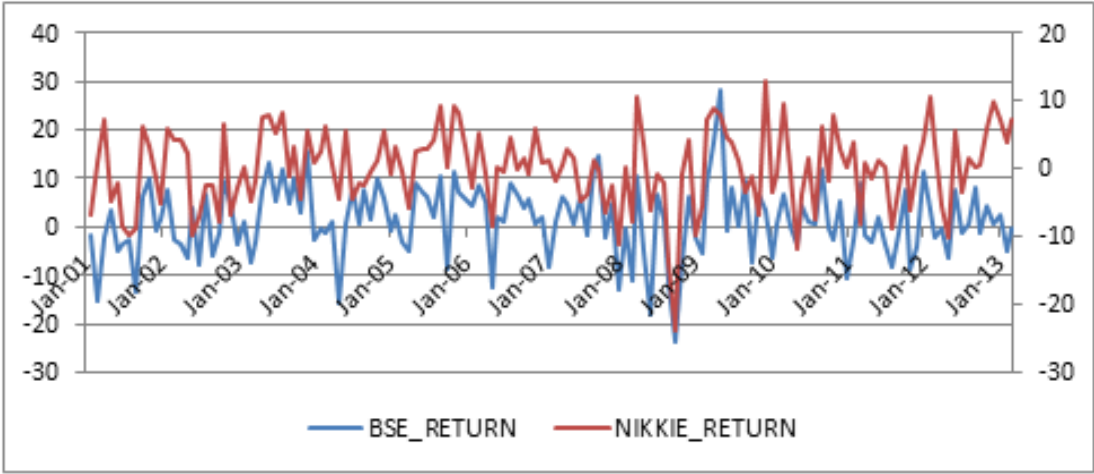

\section{BSE RETURN compare with SHANGHAI RETURN}

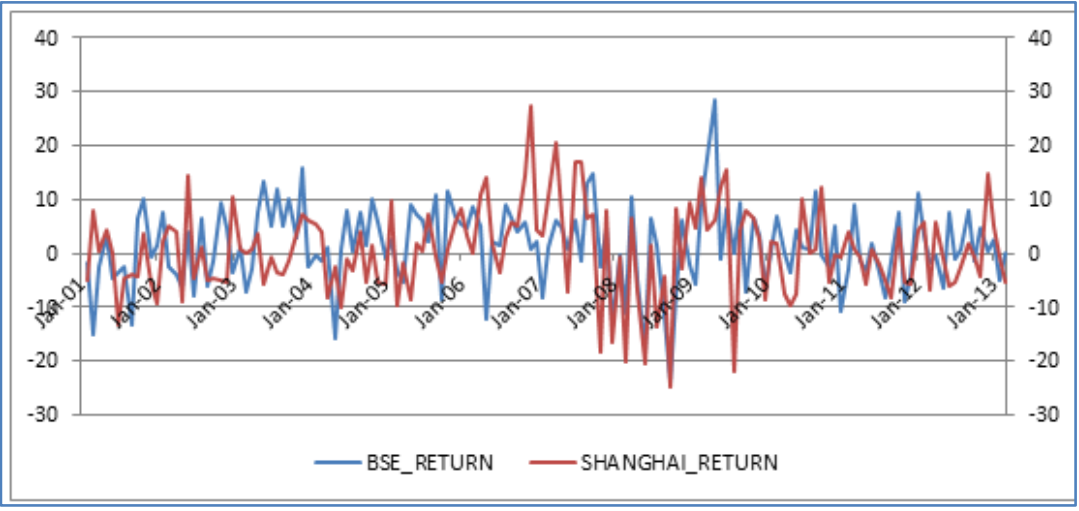

a. Determine the multiple regression equation for the data. Coefficients $^{\mathbf{a}}$

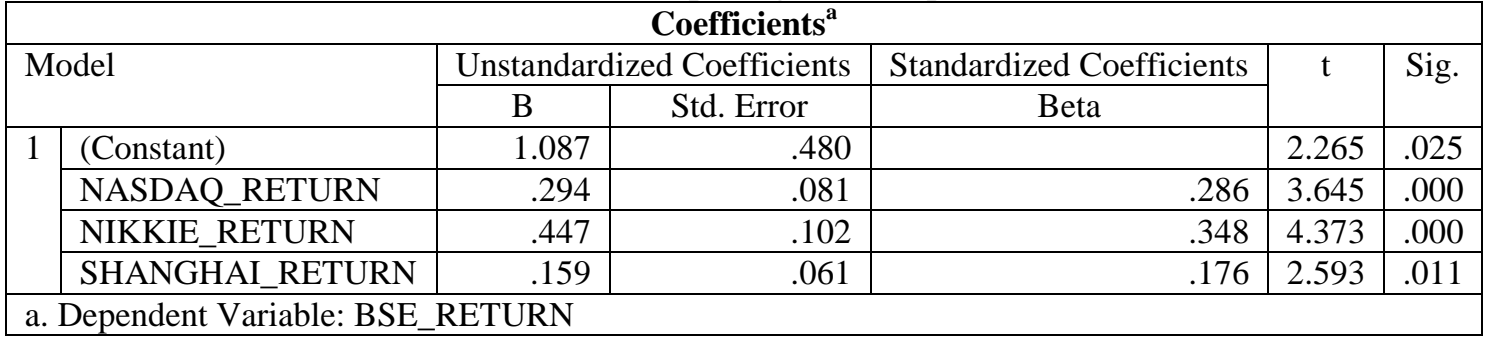

$$
y^{\wedge}=-1.087+.294 \times 1+.447 \times 2+.169 \times 3
$$

b. Compute and interpret the coefficient of multiple determinations, $R 2$.

\begin{tabular}{|l|c|c|c|c|}
\hline \multicolumn{5}{|c|}{ Model Summary } \\
\hline Model & R & R Square & Adjusted R Square & Std. Error of the Estimate \\
\hline 1 & $.635^{\text {a }}$ & .403 & .390 & 5.7851572 \\
\hline \multicolumn{7}{|c|}{ a. Predictors: (Constant), SHANGHAI_RETURN, NASDAQ_RETURN, NIKKIE_RETURN } \\
\hline
\end{tabular}

The coefficient of multiple determinations is. 403. The regression equation appears to be very useful for making predictions since the value of $\mathrm{R} 2$ is close to 1 .

At the 5\% significance level, determine if the model is useful for predicting the response.

\begin{tabular}{|l|l|r|r|r|r|c|}
\hline \multicolumn{7}{|c|}{ ANOVA $^{\mathbf{b}}$} \\
\hline \multicolumn{2}{|l|}{ Model } & Sum of Squares & \multicolumn{1}{c|}{ df } & Mean Square & F & Sig. \\
\cline { 2 - 7 } & Regression & 3208.907 & 3 & 1069.636 & 31.960 & $.000^{\mathbf{a}}$ \\
\cline { 2 - 7 } & Residual & 4752.462 & 142 & 33.468 & & \\
\cline { 2 - 7 } & Total & 7961.370 & 145 & & & \\
\hline
\end{tabular}


At the $\langle=0.05$ level of significance, there exists enough evidence to conclude that at least one of the predictors is useful for predicting BSE return therefore the model us useful.

\section{Objective 3}

To check interdependency of Indian and global stock indices movements.

Checking Interdependency of BSE Close Value (X) with NIKKIE Close Values (Y)

\begin{tabular}{|c|c|c|c|c|}
\hline \multicolumn{5}{|c|}{ Granger Causality Test: $Y=f(X)$} \\
\hline Model & Res.DF & Diff. DF & $F$ & $p$-value \\
\hline Complete model & 143 & & & \\
\hline Reduced model & 144 & -1 & 0.0563592086127705 & 0.812685539118246 \\
\hline \multicolumn{5}{|c|}{ Granger Causality Test: $X=f(Y)$} \\
\hline Model & Res.DF & Diff. DF & $\mathrm{F}$ & $p$-value \\
\hline Complete model & 143 & & & \\
\hline Reduced model & 144 & -1 & 0.00667932278359587 & 0.934977987675063 \\
\hline
\end{tabular}

From above results it is evident that,

- BSE Closing Values don't have significant dependency on Nikkie Closing Values as pvalue of Causality Granger Test is 0.812 which is greater than 0.05 (level of significance).

- NIKKIE Closing Values don't have significant dependency on BSE Closing Values as p-value of Causality Granger Test is 0.934 which is greater than 0.05 (level of significance).

- Thus, there is no evidence of interdependency of two stock indices.

Checking the interdependency of bse close and nasdaq close.

\begin{tabular}{|c|c|c|c|c|}
\hline \multicolumn{5}{|c|}{ Granger Causality Test: $\gamma=f(x)$} \\
\hline Model & Res.DF & Diff. DF F & $F$ & $p$-value \\
\hline Complete model & 143 & & & \\
\hline Reduced model & 144 & -1 & 14.6405703899552 & 0.000193788303580596 \\
\hline \multicolumn{5}{|c|}{ Granger Causality Test: $X=f(Y)$} \\
\hline Model & Res.DF & \begin{tabular}{l|l} 
& Diff. DF \\
\end{tabular} & $F$ & $p$-value \\
\hline Complete model & 143 & & & \\
\hline Reduced model & 144 & -1 & 0.56524160393271 & 110.453391634953765 \\
\hline
\end{tabular}

- BSE Closing Values have significant dependency on Nasdaq Closing Values as pvalue of Causality Granger Test is 0.000193 which is greater than 0.05 (level of significance).

- Nasdaq Closing Values don't have significant dependency on BSE Closing Values as p-value of Causality Granger Test is 0.453 which is greater than 0.05 (level of significance).

- Thus, there is evidence of interdependency of two stock indices.

Checking the interdependency of bse close with shanghai close

\begin{tabular}{|c|c|c|c|c|}
\hline \multicolumn{5}{|c|}{ Granger Causality Test: $Y=f(X)$} \\
\hline Model & Res.DF & Fiff. DF & $F$ & $p$-value \\
\hline Complete mode & 143 & & & \\
\hline Reduced model & 144 & -1 & 0.332527897669359 & 0.565080953433591 \\
\hline \multicolumn{5}{|c|}{ Granger Causality Test: $X=f(Y)$} \\
\hline Model & Res.DF & Diff. DF F & $\mathrm{F}$ & $p$-value \\
\hline Complete model & 143 & & & \\
\hline Reduced model & 144 & -1 & 0.00348221451353374 & 40.953026294601851 \\
\hline
\end{tabular}


- $\quad$ BSE Closing Values have significant dependency on shanghai Closing Values as p-value of Causality Granger Test is 0.565 which is greater than 0.05 (level of significance).

- Shanghai Closing Values don't have significant dependency on BSE Closing Values as p-value of Causality Granger Test is 0.953 which is greater than 0.05 (level of significance

- Thus, there is evidence of interdependency of two stock indices.

\section{Objective 4}

To assess perception of investors as to impact of international stock market volatility on stock market of emerging economy like India.

\section{Question 4.4.1.1}

\begin{tabular}{|l|l|}
\hline \multicolumn{2}{|c|}{ GENDER } \\
\hline MALE & 35 \\
\hline FEMALE & 23 \\
\hline
\end{tabular}

\section{Interpretation}

Among the 58 respondent the questionnaire by 35 male and 23 female.

\section{Question 4.4.1.2}

\begin{tabular}{|l|l|}
\hline \multicolumn{2}{|c|}{ AGE } \\
\hline LESS THAN 20 & 12 \\
\hline $21-35$ & 21 \\
\hline $36-50$ & 14 \\
\hline MORE THAN 50 & 11 \\
\hline
\end{tabular}

\section{Interpretation}

If we see the age factor that in 58 respondent I fill my questionnaire by 12 people which less than 20 year and 21 people which is 21-35 year and 14 people which is $36-50$ year and 11 people which is more than 50 year.
Question 4.4.1.3

\begin{tabular}{|l|l|}
\hline \multicolumn{2}{|c|}{ Occupation } \\
\hline STUDENT & 24 \\
\hline BUSINESS MEN & 11 \\
\hline GOVT. EMPLOYEE & 5 \\
\hline PRIVATE SECTOR EMPLOYEE & 10 \\
\hline SELF EMPLOYED & 8 \\
\hline
\end{tabular}

\section{Interpretation}

If we see the Occupation factor that in 58 respondents I fill my questionnaire by 24 student and 11 business men and 5 govt. employees and 10 private employees and 8 self-employees.

Through which source did you come to know about financial services?

Question 4.4.1.4

\begin{tabular}{|l|l|}
\hline \multicolumn{2}{|c|}{ Source of knowing financial services } \\
\hline ADVERTISEMENT (MEDIA) & 11 \\
\hline FRIENDS & 9 \\
\hline COMPANY OUTLET & 7 \\
\hline INTERNET & 31 \\
\hline
\end{tabular}

\section{Interpretation}

Now we see the Source of knowing financial services factor that in 58 respondent most of the people get the information form internet and 11 people from advertisement and 9 people from our friends and 7 people from company outlet.

Question 4.4.1.5
\begin{tabular}{|l|l|}
\hline $\begin{array}{l}\text { Do you think stock market research is essential } \\
\text { for investing your money to earn high returns? }\end{array}$ \\
\hline YES & 53 \\
\hline NO & 5 \\
\hline
\end{tabular}

\section{Interpretation}

Now we see that 53 people say that stock market research is essential for investing your money to earn high returns and only 5 people says no.

\section{Question 4.4.2.1}

\begin{tabular}{|l|c|c|c|c|c|}
\hline & $\begin{array}{c}\text { strongly } \\
\text { disagree }\end{array}$ & disagree & $\begin{array}{c}\text { Neither Agree } \\
\text { Nor Disagree }\end{array}$ & Agree & $\begin{array}{c}\text { Strongly } \\
\text { Agree }\end{array}$ \\
\hline $\begin{array}{l}\text { Indian stock market is affected } \\
\text { by global stock market. }\end{array}$ & 1 & 2 & 0 & 31 & 24 \\
\hline
\end{tabular}

\section{Interpretation}

If we talking about the Indian stock market is affected by global stock market now as we can see in this chart that 24 people strongly agree with this statement and 31 people are agree and only 1 and 2 people are strongly disagree and disagree.

\section{Question 4.4.2.2}

\begin{tabular}{|l|c|c|c|c|c|}
\hline & $\begin{array}{c}\text { strongly } \\
\text { disagree }\end{array}$ & disagree & $\begin{array}{c}\text { Neither Agree } \\
\text { Nor Disagree }\end{array}$ & Agree & $\begin{array}{c}\text { Strongly } \\
\text { Agree }\end{array}$ \\
\hline $\begin{array}{l}\text { As an investor when you make } \\
\text { investment in stock, global stock } \\
\text { market conditions are considered. }\end{array}$ & 2 & 4 & 2 & 23 & 27 \\
\hline
\end{tabular}




\section{Interpretation}

If we talking about the as an investor when you make investment in stock, global stock market conditions are considered. now as we can see in this chart that 27 people strongly agree with this statement and 23 people are agree and only 2 and 4 people are strongly disagree and disagree.

\section{Question 4.4.2.3}

\begin{tabular}{|l|c|c|c|c|c|}
\hline & $\begin{array}{c}\text { Strongly } \\
\text { Disagree }\end{array}$ & Disagree & $\begin{array}{c}\text { Neither Agree } \\
\text { Nor Disagree }\end{array}$ & Agree & $\begin{array}{c}\text { Strongly } \\
\text { Agree }\end{array}$ \\
\hline $\begin{array}{l}\text { Global stock market returns are } \\
\text { correlated. }\end{array}$ & 3 & 5 & 0 & 19 & 31 \\
\hline
\end{tabular}

\section{Interpretation}

If we talking about the Global stock market returns are correlated. now as we can see in this chart that 31 people strongly agree with this statement and 19 people are agree and only 3 and 5 people are strongly disagree and disagree.

Question 4.4.2.4

\begin{tabular}{|l|c|c|c|c|c|}
\hline & $\begin{array}{c}\text { Strongly } \\
\text { Disagree }\end{array}$ & Disagree & $\begin{array}{c}\text { Neither Agree } \\
\text { Nor Disagree }\end{array}$ & Agree & $\begin{array}{c}\text { Strongly } \\
\text { Agree }\end{array}$ \\
\hline $\begin{array}{l}\text { Global risk factors in stock } \\
\text { market are dependent on } \\
\text { each other. }\end{array}$ & 5 & 3 & 1 & 23 & 26 \\
\hline
\end{tabular}

\section{Interpretation}

If we talking about the Global risk factors in stock market are dependent on each other. now as we can see in this chart that 26 people strongly agree with this statement and 23 people are agree and only 3 and 5 people are strongly disagree and disagree.

\section{Question 4.4.2.5}

\begin{tabular}{|l|c|c|c|c|c|}
\hline & $\begin{array}{c}\text { Strongly } \\
\text { Disagree }\end{array}$ & Disagree & $\begin{array}{c}\text { Neither Agree } \\
\text { Nor Disagree }\end{array}$ & Agree & $\begin{array}{c}\text { Strongly } \\
\text { Agree }\end{array}$ \\
\hline $\begin{array}{l}\text { If in the morning you listen a unfavorable } \\
\text { news about a well-known international } \\
\text { stock market, your investment strategy in } \\
\text { domestic will be affected. }\end{array}$ & 3 & 2 & 5 & 26 & 22 \\
\hline
\end{tabular}

\section{Interpretation}

If we talking about the If in the morning you listen a unfavorable news about a well-known international stock market, your investment strategy in domestic will be affected. now as we can see in this chart that 22 people strongly agree with this statement and 26 people are agree and only 2 and 3 people are strongly disagree and disagree.

\section{Question 4.4.2.6}

\begin{tabular}{|l|c|c|c|c|c|}
\hline & $\begin{array}{c}\text { Strongly } \\
\text { Disagree }\end{array}$ & Disagree & $\begin{array}{c}\text { Neither Agree Nor } \\
\text { Disagree }\end{array}$ & Agree & $\begin{array}{c}\text { Strongly } \\
\text { Agree }\end{array}$ \\
\hline $\begin{array}{l}\text { As an investor you look to } \\
\text { optimize your portfolio } \\
\text { considering global risk } \\
\text { return propositions. }\end{array}$ & 4 & 3 & 0 & 17 & 34 \\
\hline
\end{tabular}

\section{Interpretation}

If we talking about as an investor you look to optimize your portfolio considering global risk return propositions. now as we can see in this chart that 34 people strongly agree with this statement and 17 people are agree and only 3 and 4 people are strongly disagree and disagree.

\section{Question 4.4.2.7}

\begin{tabular}{|l|c|c|c|c|c|}
\hline & $\begin{array}{c}\text { Strongly } \\
\text { Disagree }\end{array}$ & Disagree & $\begin{array}{c}\text { Neither Agree Nor } \\
\text { Disagree }\end{array}$ & Agree & $\begin{array}{c}\text { Strongly } \\
\text { Agree }\end{array}$ \\
\hline $\begin{array}{l}\text { Domestic Investment should } \\
\text { focus on domestic investment } \\
\text { environment only. }\end{array}$ & 3 & 5 & 2 & 31 & 17 \\
\hline
\end{tabular}




\section{Interpretation}

If we talking Domestic Investment should focus on domestic investment environment only. now as we can see in this chart that 17 people strongly agree with this statement and 31 people are agree and only 3 and 5 people are strongly disagree and disagree.

Question 4.4.2.8

\begin{tabular}{|l|c|c|c|c|c|}
\hline & $\begin{array}{c}\text { Strongly } \\
\text { Disagree }\end{array}$ & Disagree & $\begin{array}{c}\text { Neither Agree Nor } \\
\text { Disagree }\end{array}$ & Agree & $\begin{array}{c}\text { Strongly } \\
\text { Agree }\end{array}$ \\
\hline $\begin{array}{l}\text { Economic breakdown risk } \\
\text { factors disturb the stock } \\
\text { market continuously. }\end{array}$ & 2 & 7 & 0 & 33 & 16 \\
\hline
\end{tabular}

\section{Interpretation}

If we talking about Economic breakdown risk factors disturb the stock market continuously. now as we can see in this chart that 16 people strongly agree with this statement and 33 people are agree and only 2 and 7 people are strongly disagree and disagree.

Question 4.4.2.9

\begin{tabular}{|l|c|c|c|c|c|}
\hline & $\begin{array}{c}\text { Strongly } \\
\text { Disagree }\end{array}$ & Disagree & $\begin{array}{c}\text { Neither Agree } \\
\text { Nor Disagree }\end{array}$ & Agree & $\begin{array}{c}\text { Strongly } \\
\text { Agree }\end{array}$ \\
\hline $\begin{array}{l}\text { Market value fluctuations risk } \\
\text { factors disturb the stock market. }\end{array}$ & 3 & 5 & 2 & 27 & 21 \\
\hline
\end{tabular}

\section{Interpretation}

If we talking about Market value fluctuations risk factors disturb the stock market. now as we can see in this chart that 21 people strongly agree with this statement and 27 people are agree and only 3 and 5 people are strongly disagree and disagree.

Question 4.4.2.10

\begin{tabular}{|l|c|c|c|c|c|}
\hline & $\begin{array}{c}\text { Strongly } \\
\text { Disagree }\end{array}$ & Disagree & $\begin{array}{c}\text { Neither Agree } \\
\text { Nor Disagree }\end{array}$ & Agree & $\begin{array}{c}\text { Strongly } \\
\text { Agree }\end{array}$ \\
\hline $\begin{array}{l}\text { The theory of cross market } \\
\text { spillovers holds practical } \\
\text { relevance for investment in } \\
\text { contemporary scenario. }\end{array}$ & 2 & 3 & 0 & 31 & 22 \\
\hline
\end{tabular}

\section{Interpretation}

If we talking about The Theory of cross market spillovers holds practical relevance for investment in contemporary scenario. now as we can see in this chart that 22 people strongly agree with this statement and 31 people are agree and only 2 and 3 people are strongly disagree and disagree.

\section{FINDINGS}

The results presented in this work confirm that there is an interconnection between the BSE and the other Stock Market.

1. There is evidence for various information spillovers across the markets from returns as well as from news sentiments.

2. The coefficients also suggest spillovers from the returns to the sentiments across markets.

3. The coefficients indicate that high absolute sentiment scores in the stock market are expected to have an increasing influence on the commodity returns and a decreasing influence on the stock returns of the following day.

4. The findings of the growing correlations between the two markets it supports the theory that the stock market are converging.
5. The data gives evidence for information spillovers from news sentiments. It is to assume that the news article-writing analysts are influenced by the news sentiments of the previous day.

6. In terms of the Granger Causality this would indicate that there is no lead of the sentiments on the returns.

\section{CONCLUSION}

Their conclusion is based on the assumption that the prices tend to anticipate future news flows. As a consequence the prices rise previously to good news and decrease to previously bad news within a market. This effect could explain the little stock price reaction that is observed after news events. Links across markets could potentially appear not only in returns and sentiment scores but also in return and sentiment score volatilities. Due to the fact that the findings for spillover effects from sentiments to returns were moderate, the next step was to explore if there were at least any volatility spillovers from sentiments to returns. The findings give evidence for various spillover effects during the expansion period. 
The volatilities of the impact from the stock market is positive and significant for a one-day lag. The coefficients indicate that high absolute sentiment scores in the stock market are expected to have a decreasing influence on the stock returns of the following day. Surprisingly enough the volatility of the stock market sentiment has no significant influence on the volatility of the stock returns. During the contraction period the sentiment volatility spillovers need more time to incorporate into prices. But still there are significant positive volatility spillovers across the markets. Overall, the model for the lead-lag relation in volatilities finds significance for a link between the sentiments and the returns. But there is no consistent direction of the volatility spillovers. Additionally the magnitudes of the coefficients are again very small. Based on the analysis results presented herein one cannot conclude whether one market primarily leads the other. The cross relations over various interdependences made it difficult to define clear lead-lag relations between the commodity and the stock market note that there are various linkages between the two markets and that portfolio manager would be well advised to give attention to it.

\section{REFERENCES}

1. Miller, M. H. (1991). Financial Innovations and Market Volatility, Blackwell, 1-288.

2. Chatrath, A., Ramchander, S., \& Song, F. (1996). The Role of Futures Trading Activity in Exchange Rate Volatility. Journal of Futures Markets. 16(5):561-584.

3. Barry, C. B., Peavy Jr, J. W., \& Rodriguez, M. (1998). Performance characteristics of emerging capital markets. Financial Analysts Journal, 54(1), 72-80.

4. Arshanapalli, B., \& Kulkarni, M. S. (2001). Interrelationship between Indian and US stock markets. Journal of Management Research, 1(3), 141-148.

5. Patel, J. B. (2003). Inter-temporal relationship between The US stock market and the emerging markets of Asia. Journal of Business \& Economics Research (JBER), 1(10).

6. Rahman, S. (2001). The introduction of derivatives on the Dow Jones Industrial Average and their impact on the volatility of component stocks. Journal of Futures Markets: Futures, Options, and Other Derivative Products, 21(7), 633-653.

7. Figuerola-Ferretti, I., \& Gilbert, C. L. (2001). Price variability and marketing method in nonferrous metals:: Slade's analysis revisited. Resources Policy, 27(3), 169-177.

8. Bologna, P., \& Cavallo, L. (2002). Does the introduction of stock index futures effectively reduce stock market volatility? Is the'futures effect'immediate? Evidence from the Italian stock exchange using GARCH. Applied Financial Economics, 12(3), 183-192.

9. Chiang, M-H., \& Wang, C. Y. (2002). The impact of futures trading on spot index volatility: Evidence for Taiwan index futures. Applied Economics Letters, 9(6), 381-385.

10. Faff, R. W., \& McKenzie, M. D. (2002). The impact of stock index futures trading on daily returns seasonality: A multicountry study. The Journal of Business, 75(1):95-125.

11. Schwert, G. W. (1989). Why does stock market volatility change over time?. The journal of finance, 44(5), 1115-1153.

12. Sarangi, S. B., \& Patnaik, U. S. (2007). A study on the impact of futures and options on spot market volatility: A case of S\&P CNX Nifty Index. The Icfai Journal of Applied Finance, 13:5872

13. Thenmozhi, M. (2002). Futures trading, information and spot price volatility of NSE-50 Index Futures Contract. NSE Working Paper. http://www.nseindia.com/content/ research/ Paper59.pdf (accessed on 10 March 2005).

14. Pilar, C., \& Rafael, S. (2002). Does derivatives trading destabilize the underlying assets? Evidence from the Spanish stock market. Applied Economics Letters, 9(2), 107-110.

15. Robert, W. F., \& Michael, D. M. (2002). The impact of stock index futures trading on daily returns seasonality: A multicountry study. The Journal of Business, 75(1):95-125.

16. Shenbagaraman, P. (2003). Do futures and options trading increase stock market volatility?. NSE Research Initiative paper, 71.

17. Bae, S. C., Kwon, T. H., \& Park, J. W. (2004). Futures trading, spot market volatility, and market efficiency: The case of the Korean index futures markets. Journal of Futures Markets: Futures, Options, and Other Derivative Products, 24(12), 1195-1228.

18. Taylor, C. (2004). Modern social imaginaries. Duke University Press.

19. Boyer, C. M., \& Popiela, M. E. (2004). Index futures and stock price volatility. Journal of Derivatives \& Hedge Funds, 9(4), 351.

20. Floros, C., \& Vougas, D. V. (2006). Index futures trading, information and stock market volatility: The case of Greece. Derivatives Use, Trading \& Regulation, 12(1-2), 146-166.

21. Sibani, P. S., \& Uma, S. P. (2007). A study on the impact of futures and options on spot market volatility: A case of S\&P CNX Nifty Index. ICFAI Journal of Applied Finance, 13(4), 58-72.

22. Raju, M. T. (2004). Stock Market Volatility - An International Comparison., Working Paper Series 01/09. 